\title{
Improving the performance of red and white currants in high latitude conditions by training methods
}

\author{
Karhu, Saila \\ International Society for Horticultural Science, ISHS \\ 2020-04
}

\begin{abstract}
Karhu , S , Bles , C , Laine , K \& Palonen, P 2020 , Improving the performance of red and white currants in high latitude conditions by training methods . in C Carlen, $E$ Krüger \& $G$ Muster (eds) , Acta Horticulturae. Acta Horticulturae, no. 1277 , International Society for Horticultural Science, ISHS , pp. 225-231, XII International Rubus and Ribes Symposium: Innovative Rubus and Ribes Production for High Quality Berries in Changing Environments, Zürich , Switzerland , 23/06/2019 . https://doi.org/10.17660/ActaHortic.2020.1277.32
\end{abstract}

http://hdl.handle.net/10138/329175

https://doi.org/10.17660/ActaHortic.2020.1277.32

unspecified

acceptedVersion

Downloaded from Helda, University of Helsinki institutional repository.

This is an electronic reprint of the original article.

This reprint may differ from the original in pagination and typographic detail.

Please cite the original version. 


\title{
Improving the performance of red and white currants in high latitude conditions by the training methods
}

\author{
S. Karhu'1a, C. Bles², K. Laine ${ }^{3}$ and P. Palonen ${ }^{3}$ \\ ${ }^{1}$ Natural Resources Institute Finland (Luke), Turku, Finland; ${ }^{2}$ Hochschule Geisenheim University Geisenheim, \\ Germany; ${ }^{3}$ Department of Agricultural Sciences, University of Helsinki, Finland.
}

\begin{abstract}
Red and white currants (Ribes rubrum group) are most often grown in a bush training system in the Northern European countries. We studied fruit production of red and white currant cultivars in three different trials by training the plants on wires as cordons. When red currants grown before in bush form in open field were converted to cordon system, their yield was reduced to be in the first year on average $38 \%$ and in the second year $61 \%$ of the yield of bush-form plants. When, however, a biennial pruning system by retaining previous-year yielding branches in addition to new ones was used, the yield of cordon plants exceeded that of bush-form plants. Fruit size was also improved by $36 \%$ while the number of berries per raceme was unaffected. The cultivar 'Punahilkka' produced longest racemes with a high number of berries, making it the most suitable for fresh fruit marketing. The biennial pruning method was compared to annual-shoot pruning method in two red currant cultivars planted in a cordon training system in a high polytunnel. The biennial method resulted in the yield increase of $130 \%$ in one cultivar but only $31 \%$ in another cultivar. Berries of long side branches were larger than those developed on main trunks in shortened fruiting spurs. Two white currant cultivars were grown as cordons with different number of annual cropping side branches. A larger proportion of total crop was produced in long side shoots in 'Lepaan Valkea' than in 'Piikkiön Helmi'. Increasing the number of long annual side shoots higher than five per main trunk improved the yield of that cultivar.
\end{abstract}

Keywords: fresh fruit, cordon, pruning, Ribes, trellising

\section{INTRODUCTION}

Currant (Ribes) fruit is consumed fresh or processed into juices, jams, preserves, teas and liqueurs, and berries can also be used for production of natural food colorants (MikulicPetkovsek et al., 2016). In recent years there has been an increased interest toward the genus Ribes, due to the high content of bioactive ingredients of fruit associated to human health benefits (Mattila et al., 2016).

Due to the low profitability of conventional production, growers are interested in producing red and white currants (Ribes rubrum group) of superior quality for fresh fruit marketing (Pluta et al., 2012). The cropping potential and fruit quality of red and white currants are, among other factors, related to production site, cultivar and also the training system, affecting the profitability of production (Ançay and Carlen, 2016). Cordon training system of Ribes plants is already a standard practice for growers in Holland, when fruit is intended for fresh market (McKay, 2005). In Nordic countries the bush training system is prevailing, but there is already some experience of growing red and white currants in cordon training system in southern Norway (Strbac, 2013).

The challenge in the production of red and white currants for fresh consumption, frequently used also because of their ornamental value, is to produce high quality fruit clusters, with berries large enough. In the very northern part of Europe, there is only a restricted number of cultivars available that suits to our growing conditions. To improve the fruit external quality, it is crucial to start to employ productions systems that increase quality but also give sufficient level of production.

a E-mail: saila.karhu@luke.fi 
We converted the red and white currant plants growing in bush training system to cordons, and tested different cultivars in that system. Also pruning practices were studied to improve the productivity of plants.

\section{MATERIALS AND METHODS}

Three separate field trials were performed at the Piikkiö research site of Natural Resources Institute Finland (Luke) in Kaarina, in southwestern Finland ( $60^{\circ} 23^{\prime} \mathrm{N}, 22^{\circ} 33^{\prime}$ E). All plants were planted with a row spacing of $4 \mathrm{~m}$ and a plant spacing of $0.8 \mathrm{~m}$ in a row. Trellising system was built to plants in the beginning of the experiments, and cordon main trunks were tied vertically to wires with the help of bamboo canes. In Experiments 1 and 3, the bushes were converted to cordons by selecting three youngish branches to become cordons and removing other branches. In Experiment 2 the plants were planted and grown as three-trunk cordons from the beginning. The soil type was silt in Experiment 1 and silt moraine in Experiments 2 and 3, all rich in organic matter. The rows were mulched by black woven polypropylene cloth.

During summer months, water and compound fertilizers were applied in equal amounts to all plants within each experiment via a trickle tape and by surface broadcast. Scheduling of irrigation was employed by using automatic tensiometers at $25 \mathrm{~cm}$ depth under the soil level, using soil moisture potential of -15 or $-20 \mathrm{kPa}$ as target threshold. The level of fertilization was increased according to the development of plants and was also due to the nutrient status of soil; the nutrients given annually, as kg per hectare, varied as follows: N: 10-64, P: 0.3-33, and K: 13-86. Standard plant protection by insecticides and fungicides were applied when necessary. All cordon plants were harvested by hand, bushtrained plants also by using rubber poles. Yield was weighed, and the average berry weight was measured and expressed as the mass of 100 berries. Weighted means were calculated, when relevant to show average values for berry size.

For statistical analyses of data, SAS MIXED procedure was used to fit the mixed models by the restricted maximum likelihood (REML) estimation method (SAS Institute Inc., Cary, USA). The significance of the estimated difference was investigated at $95 \%$ confidence intervals.

\section{Experiment 1. Red currants in bush and cordon training}

The old European cultivar 'Red Dutch', the Finnish cultivar 'Punahilkka' and an unnamed selection 'L110' from the Luke breeding program (called cultivar in this article) were planted for open field production in 2009 and grown as bush-trained plants. In early spring 2015 a part of the bushes were converted to cordons, and another part was still trained as bushes. Three to four replicated plots with two to three plants per plot, at least 8 plants per both treatments of each cultivar were used. In 2015 and 2016, four medium-sized side branches developed in previous year in each main trunk were kept to bear fruit and shortened to ca. $30 \mathrm{~cm}$. Other branches were shortened to one to two node stubs or short spurs and the pruning method was called annual pruning (all side branches renewed annually). In 2016 a biennial pruning method was used: in each trunk the four side branches that fruited previous year were kept, in addition to the four new side branches, other branches were shortened to small spurs.

\section{Experiment 2. Pruning of red currant cordons}

The small plants of 'Punahilkka' and 'L110' were planted in a high walk-in tunnel in spring 2014 in a three-trunk cordon trellising system. There were three replicated plots with six plants of each cultivar. In each plot, a half of the plants were pruned by annual pruning method and a half by biennial pruning method, as described in Experiment 1 for cropping in 2017.

\section{Experiment 3. Pruning of white currant cordons}


The Finnish white currant cultivars 'Lepaan Valkea' and 'Piikkiön Helmi' were planted for open field production in 2009 and grown as bush-trained plants. In early spring 2014 the bushes were converted to cordons, and 'Lepaan Valkea' was covered by a high polytunnel. On each of three main trunks, 0 (in 2014 only), 5, 10 or 15 side branches were annually kept to produce yield. For each cultivar and treatment there were five replicated plots with one plant per plot.

\section{RESULTS}

The red and white currant plants converted to cordon training from bush training system produced some crop already during the year of conversion, but full effect of training system could be seen later. A considerable number of suckers were developed at the base of plants converted from bush-training to cordon training, and they were regularly removed. The red currants planted in 2014 in cordon training produced the first proper crop in 2017. No winter or spring frost damages were observed during the test years. Exceptionally hot and dry summer weather probably reduced yields in 2018, and in the same year, when no plant protection was used, 'L110' also suffered from gooseberry mildew (Podosphaera (syn. Sphaerotheca) mors-uva).

\section{Red currants in bush and cordon training}

When three red currant cultivars grown before in bush form in the open field were pruned and converted to the cordon system in 2015, their yield was reduced, as expected, to be on average $38 \%$ of the yield of the bush-form plants in that year. In 2016 the difference was smaller, and the yield of the cordon plants was on average $61 \%$ of the yield of the bushform plants. The cultivars responded in different way, however, and no significant difference was found in the yield of 'L110' during these two first years due to the training system, whereas the largest yield reduction was found in 'Punahilkka' (Table 1).

When the biennial pruning system by retaining the yielding branches of the previousyear in addition to new ones was used, the yield of cordon plants in 2017 exceeded that of bush-form plants by $42 \%$.

Table 1. Yield and berry size of red currants in cordon and bush training. The values are LS means of 3-4 replicates. Pair-wise comparisons are within each cultivar and year1.

\begin{tabular}{|c|c|c|c|c|c|c|c|c|c|}
\hline \multirow[t]{2}{*}{ Cultivar } & & \multicolumn{2}{|l|}{2015} & \multicolumn{2}{|l|}{2016} & \multicolumn{2}{|l|}{2017} & \multirow{3}{*}{$\begin{array}{l}\text { Variable } \\
\text { Cultivar }(\mathrm{C}) \\
\text { Year }(\mathrm{Y})\end{array}$} & \multirow{2}{*}{$\frac{P}{0.007}$} \\
\hline & Yield per & ant $(g)$ & & & & & & & \\
\hline L110 & Cordon & 2437.8 & NS & 2343.6 & NS & 4728.6 & * & & $<.001$ \\
\hline L110 & Bush & 3495.5 & & 2140.1 & & 3418.6 & & Training(T) & 0.006 \\
\hline Punahilkka & Cordon & 181.9 & $* * *$ & 1179.1 & $* * *$ & 3306.3 & NS & $C^{*} Y$ & 0.002 \\
\hline Punahilkka & Bush & 2812.2 & & 3683.5 & & 2274.4 & & $C^{*} T$ & 0.018 \\
\hline Red Dutch & Cordon & 424.5 & ** & 1581.8 & * & 5378.9 & ** & $Y^{*} T$ & $<.001$ \\
\hline \multirow[t]{2}{*}{ Red Dutch } & Bush & 2491.4 & & 2936.3 & & 3732.4 & & $C^{*} Y^{*} T$ & 0.407 \\
\hline & \multicolumn{5}{|c|}{ Weight of 100 berries $(\mathrm{g})$} & & & C & $<.001$ \\
\hline L110 & Cordon & 78.1 & $* * *$ & 63.0 & $* * *$ & 58.7 & *** & Y & 0.002 \\
\hline L110 & Bush & 50.0 & & 49.7 & & 44.1 & & $\mathrm{~T}$ & $<.001$ \\
\hline Punahilkka & Cordon & 51.0 & $* * *$ & 54.1 & $* * *$ & 49.3 & NS & $C^{*} Y$ & $<.001$ \\
\hline Punahilkka & Bush & 39.7 & & 37.9 & & 44.1 & & $C^{*} T$ & 0.001 \\
\hline Red Dutch & Cordon & 79.8 & $* * *$ & 95.4 & $* * *$ & 77.7 & $* * *$ & $Y^{*} T$ & 0.001 \\
\hline Red Dutch & Bush & 49.1 & & 68.6 & & 63.2 & & $C^{*} Y^{*} T$ & 0.067 \\
\hline
\end{tabular}

$1 *,{ }^{* *},{ }^{* * *}$ Significant at $P<0.05, P<0.01$ and $P<0.001$, respectively; NS $=$ nonsignificant.

As determined in 2017 in the cordon plants trained by biennial pruning method, the division of the yield harvested from longer side branches and from the short spurs on main 
trunks showed a significant difference of the cultivar 'Punahilkka' from the other cultivars: in 'Punahilkka' $75 \%$ of crop was harvested from side branches, in 'Red Dutch' the proportion was $64 \%$ and in 'L110' it was $60 \%$ with $95 \%$ confidence intervals [CIs] of [67, 85], [55, 72] and $[50,70]$, respectively.

The number of berries per raceme, determined in 2017, was affected by the cultivar but not by the training system or position of the raceme (side branches or short spurs on main trunks) in the plants. 'Punahilkka' had a higher number of berries in a raceme (15.5) than 'Red Dutch' (7.1) or 'L110' (6.6), with 95\% CIs [14.9, 16.2], [6.4, 7.8] and [5.9, 7.4], respectively.

Fruit size was improved by using the cordon instead of bush training system (Table 1). This difference was on average $36 \%$, when all cultivars and years were considered. Significant difference was also observed between all three cultivars, even though the difference varied according to the test year and training method, 'Red Dutch' having the largest berries and 'Punahilkka' the smallest ones. Fruit size also varied due to their position either in side branches or in shorts spurs on main trunks, as determined separately in 2017 in cordon-trained plants: the average mass of 100 berries was $74 \mathrm{~g}$ with $95 \%$ CIs $[68,80], 55$ $\mathrm{g}[48,62]$ and $48 \mathrm{~g}[42,54]$ for the yield of main trunks of 'Red Dutch, 'L110' and 'Punahilkka', respectively, while the corresponding values for the yields of the side shoots were $80 \mathrm{~g}[74,86], 61 \mathrm{~g}[54,68]$ and $50 \mathrm{~g}[44,55]$.

\section{Pruning of red currant cordons}

When the pruning methods were compared in two red currant cultivars planted in cordon training system in a high polytunnel, the biennial method resulted in the yield increase of $130 \%$ in 'Punahilkka', as compared to annual pruning method. In 'L110' the increase was 31\%, the difference being statistically non-significant, however (Table 2).

Similarly to the previous trial, in 'Punahilkka' a higher proportion of yield developed in side shoots than in 'L110'. The biennial pruning method increased the proportion of yield in side branches in both cultivars (Table 2).

The number of berries per raceme was affected by the pruning treatment when the yield of side branches was considered ( $p$ 0.018): on average the annual pruning method resulted in 1.5 berries more per raceme than biennial pruning method, with $95 \%$ CI [0.3, 2.7]. There was no such significant difference in the racemes in the short spurs on main trunks. In the total yield, this difference was seen as a trend only (Table 2).

Fruit size was not affected by the pruning method but annual variation was large. Notably, berries were larger in long side branches than in short spurs on main trunks.

\section{Pruning of white currant cordons}

White currant cultivars responded in different way to the number of side branches that were left on main trunks as bushes were converted to cordons with three main trunks: The plants of 'Piikkiön Helmi' with all longer side branches removed produced in 2015 a yield of $1040 \mathrm{~g}$, with $95 \% \mathrm{CI}[609,1472]$ per plant, five side branches per trunk increasing the total yield only by $9 \%$, ten side branches by $26 \%$ and 15 side branches by $42 \%$. In 2015 , the 'Lepaan Valkea' plants with cordon trunks without long side branches yielded $1765 \mathrm{~g}$ with $95 \%$ CI $[1333,2196]$ per plant, five side branches per trunk increasing the total yield by $49 \%$, ten side branches by $80 \%$ and 15 side branches by $85 \%$.

When the plants with 5,10 or 15 side branches per main trunk were compared during the three years after converting the bushes to cordon training, the plants with the lowest number of side branches produced lower yield than the plants with 10 or 15 side branches ( $p<0.059)$. The difference was most apparent during the last year (Table 3).

The size of berries was strongly affected by the cultivar and the year $(p<0.001)$. The pruning method had a much smaller effect $(p=0.096)$. The smallest berries, as measured as the mass of 100 berries in both cultivars, were in plants with the lowest number of side branches: In 'Lepaan Valkea', the values for plants with 5, 10 and 15 side shoots per trunk were respectively 71,76 and 76 grams, with 95\% CI [67, 75], [72, 80] and [72, 79], and 
corresponding values in 'Piikkiön Helmi' were 63, 66 and 65 grams, with 95\% CI [60, 67], $[63,70]$ and $[61,69]$.

Table 2. Yield and fruit characteristics of red currants growing in a tunnel in cordon training and pruned either by annual or biennial pruning method. The values are LS means of 3 replicates. Pair-wise comparisons are within each cultivar and year ${ }^{1}$.

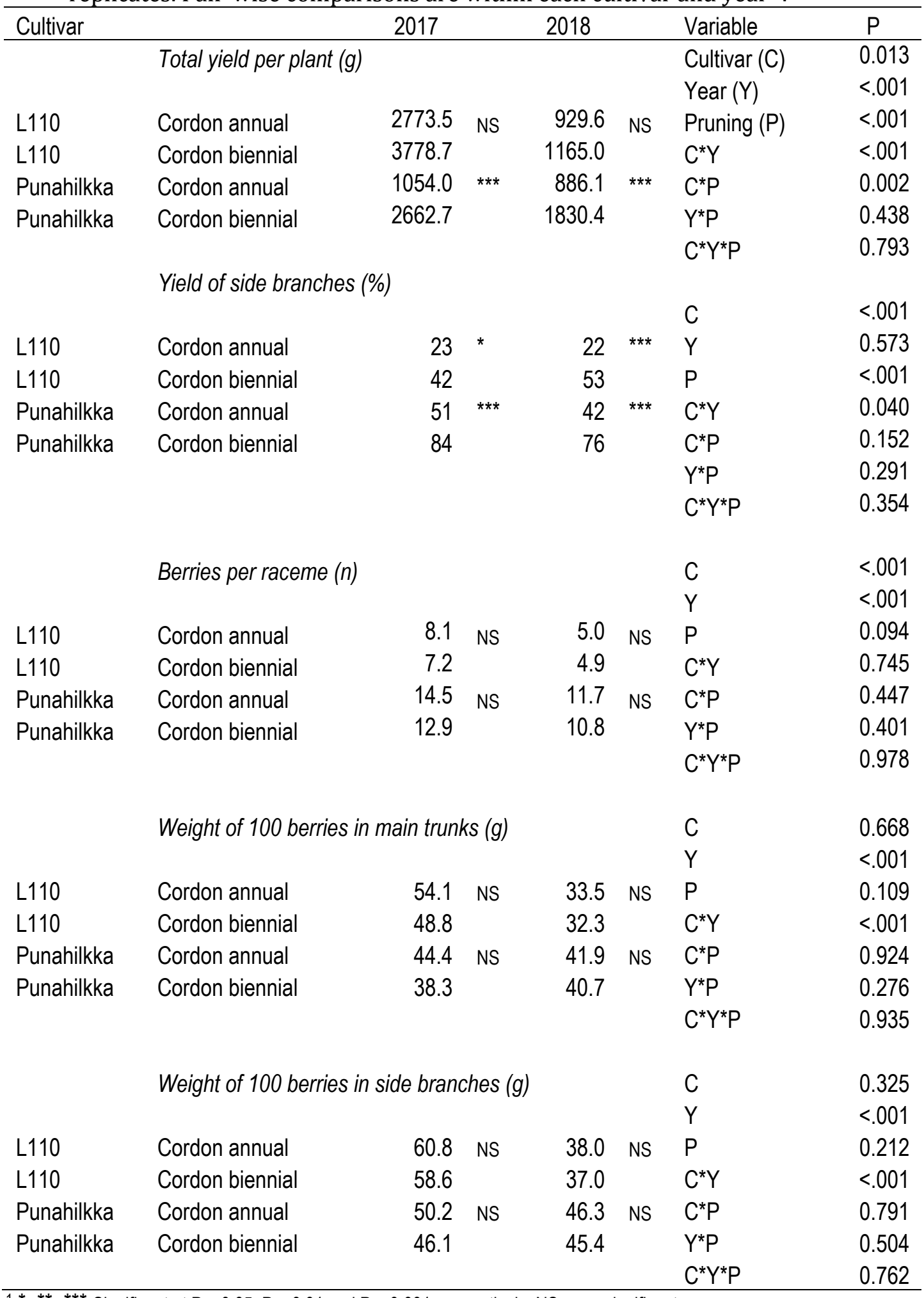

$1{ }^{*},{ }^{* *},{ }^{* * *}$ Significant at $\mathrm{P}<0.05, \mathrm{P}<0.01$ and $\mathrm{P}<0.001$, respectively; $\mathrm{NS}=$ nonsignificant. 
Table 3. Yield of white currants in cordon training and pruned to carry 5-15 cropping side branches. The values are LS means of 5 replicates. Treatment comparisons are within each cultivar and year ${ }^{1}$.

\begin{tabular}{|c|c|c|c|c|c|c|c|c|c|}
\hline \multirow[t]{2}{*}{ Cultivar } & \multirow{2}{*}{$\begin{array}{l}\text { Side } \\
\text { branches } \\
(\mathrm{n})\end{array}$} & \multicolumn{6}{|c|}{ Yield per plant (g) } & \multirow[t]{2}{*}{ Variable } & \multirow[t]{2}{*}{$P$} \\
\hline & & 2015 & & 2016 & & 2017 & & & \\
\hline Lepaan & 5 & 2642.7 & $\mathrm{~b}$ & 2449.8 & $a$ & 3225.9 & $\mathrm{~b}$ & Cultivar (C) & $<.001$ \\
\hline \multirow[t]{2}{*}{ Valkea } & 10 & 3202.3 & $b c$ & 2533.0 & a & 3817.4 & $b c$ & Year (Y) & $<.001$ \\
\hline & 15 & 3289.3 & ac & 2684.5 & a & 4359.5 & ac & $\begin{array}{l}\text { Pruning }(P) \\
C^{*} Y\end{array}$ & $\begin{array}{l}0.002 \\
<.001\end{array}$ \\
\hline Piikkiön & 5 & 1156.8 & $a$ & 1563.9 & $a$ & 1185.1 & $b$ & $C^{*} P$ & 0.472 \\
\hline \multirow[t]{2}{*}{ Helmi } & 10 & 1332.1 & $a$ & 1626.5 & $a$ & 1505.4 & $a b$ & $Y^{*} P$ & 0.091 \\
\hline & 15 & 1503.4 & $a$ & 1399.2 & $a$ & 2038.7 & a & $C^{*} Y^{*} P$ & 0.970 \\
\hline
\end{tabular}

${ }^{1}$ Mean values followed by the same letter do not differ significantly at $P=0.05$.

\section{DISCUSSION}

It was shown that red and white currants could be easily converted from bush to cordon training, as also suggested by McKay (2005). However, the effect of the change of cultivation method depended on the cultivar; In red currants, in two out of three cultivars the first year yield was almost lost, and the yield was strongly reduced also during the second year, as compared to the bush-trained plants. It seems that at least in our high latitude conditions 'Red Dutch' and 'Punahilkka' develop one-year-old side branches that do not have a high yielding potential. The still unnamed 'L110' reacted to the conversion to the cordon training system in different way, with little change in yield. Red currant carries its yielding potential in spurs and buds of the main trunks, in addition to the yield produced in long side branches (Palonen and Voipio, 1994), and 'L110' was shown to bear a major part of the yield in the short spurs and buds of the main trunk. This result was repeated with young plants in our other trial established as cordon system in polytunnel. The 'L110' cultivar thus has potential for cordon training system even with yielding shoots annually renewed.

When a biennial cordon training system was performed by retaining also the previous year's cropping side shoots, the yield potential of cordon plants even exceeded that of bush-trained plants. Even in tunnel conditions, where longer growing seasons can be created, annual pruning system resulted in 'Punahilkka' low yields. Biennial pruning seems to be a promising method for cordon-training system in northern conditions and at least in some cultivars adapted to these conditions. Yields higher in cordon than in bush-training system in one study year may be due to better pollination (Koltowski et al., 1999) and resource distribution leading a high number of flowers in upright shoots in cordon plants (Palonen and Voipio, 1994). Cordon training even improves light conditions of shoots, and Toldam-Andersen and Hansen (1993) found that the development of black currant $(R$. nigrum) flowers is favoured by high level of light, which can increase yield. When cultivation practices are adapted to support side branch development and yielding, high crops can be expected in cordon-trained plants pruned by biennial system.

Cordon training improved berry size, as compared to bush training. Berries were also larger in long side branches than in shortened spurs on main trunks, which shall be kept in mind when pruning method is selected. Also the selection of cultivar strongly affected fruit size. The old European 'Red Dutch' showed its potential as cordon in that respect. On the other hand, 'Punahilkka' produced long racemes with a high number of berries, making them the most suitable for fresh fruit marketing. It has been reported that pruning stimulates plants to produce long clusters (Mikulic-Petkovsek, 2016). In our experiments 
the number of berries per raceme was little affected by the cultivation method, showing quite strong genetic regulation.

The Finnish white currants 'Lepaan Valkea' and 'Piikkiön Helmi' were both suitable for growing in cordon system, 'Lepaan Valkea' being more productive, even when the side shoots were renewed annually. A larger proportion of crop was produced in long side shoots in 'Lepaan Valkea' than in 'Piikkiön Helmi', and increasing the number of long annual side shoots higher than five improved its yield already in a year after converting bushes to cordons. The difference between cultivars may change later when main trunks grow older and their fruiting characteristics may change (Barney, 1997). The results, however, also indicated that the production efficiency of the high number of long side branches could not be exploited before the main trunks were fully developed in height in the third harvesting year.

Increasing the number of long side branches in white currants had a trend to increase fruit size. Based on our results in red currants, the latter can be supposed to be due to the higher proportion of berries developed in long side shoots with larger fruit than those in short spurs at main trunks.

\section{CONCLUSIONS}

Cordon training of red and white currants gave best results in high latitude conditions when pruning systems favouring production in long side branches instead of spurs at main trunks were employed. Also the choice of cultivar is critical in the cordon training system for high production and long racemes.

\section{ACKNOWLEDGEMENTS}

We gratefully acknowledge financial support for this work from the Ministry of Agriculture and Forestry, Finland (Grant no. 1900/312/2013) and from the Maiju and Yrjö Rikala Horticultural Foundation. We also thank the technical staff at Luke Piikkiö.

\section{Literature Cited}

Ançay, A., and Carlen, C. (2016). Influence of training systems and of cultivars on profitability of red currant production for fresh consumption. Acta Hortic. 1133, 223-226.

Barney, D. (1997). Currants, gooseberries, and jostaberries. J. Small Fruit \& Viticulture 4, 107-142.

Koltowski, Z., Pluta, S., Jablonski, B., and Szklanowska, K. (1999). Pollination requirements of eight cultivars of black currant (Ribes nigrum L.). J. Hortic. Sci. Biotech. 74, 472-474.

McKay, S.A. (2005). Improved fresh fruit quality of gooseberries and red currants with the cordon training system. New York Fruit Q. 13, 29-32.

Mattila, P.H., Hellström, J., Karhu, S., Pihlava, J.-M., and Veteläinen, M. (2016). High variability in flavonoid contents and composition between different North-European currant (Ribes spp.) varieties. Food Chem. 204, 1420. doi: 10.1016/j.foodchem.2016.02.056

Mikulic-Petkovsek, M., Koron, D., and Veberic, R. (2016). Quality parameters of currant berries from three different cluster positions. Sci. Hortic. 210, 188-196.

Palonen, P., and Voipio, I. (1994). Floral buds, number of flower initials and fruit set in redcurrant (Ribes rubrum L.). Sci. Hortic. 58, 187-196.

Pluta, S., Żurawicz, E., and Pruski, K. (2012). Suitability of fruits of selected blackcurrant (Ribes nigrum L.) cultivars for fresh market. J. Berry Res. 2, 23-31.

Strbac, S. (2013). Cordon training system for black and red currants. http://archive.northsearegion.eu/files/

repository/20131030132938_NO-Enclosure29.pdf Norsk Landbruksrådgiving.

Toldam-Andersen, T., and Hansen, P. (1993). Growth and development in black currants (Ribes nigrum). I. Effects of light and leaf-shoot removals on growth distribution and fruit drop. Acta Hortic. 352, 237-246. 